\title{
第26回 日本爬虫両棲類学会大会記録
}

\author{
昭和62年11月 1 日 於横浜市立大学
}

The 26th Annual Meeting of the Herpetological Society of Japan November 1, 1987, at Yokohama City University

\section{大会記事}

第26回日本爬虫両棲類学会大会は, 昭和62年 11月 1 日（日）横浜市立大学医学部の新設（62 年 3 月完成）キャンパスで開催された。午前 10 時半, 深田会長加ら開会の挨拶, 第 2 解剖学教 室主任教授楠木豊和先生の挨拶, ゴリス大会準 備委員長から運営上の注意事項の説明があり,

一般講演へと移った。一般講演は去年に続いて 今年屯演題が多いため, 二つの会場に分れて, それぞれ爬虫類、画棲類を中心に行なわれた。

昼休みには玄関前広場の噴水彫刻をバックに 記念撮影, 生協での昼食に続いて希望者による ヘビの飼育施設の見学があった。午後 1 時から
昭和62年の総会がもたれ，三島章義氏を議長に 諸報告が承認された。続いて午後の一般講演が 行水れ，最後に柴田敏隆氏を議長に30分間一般 討論が行われ，午後 5 時大会を終了した。

会場への交通が不便にもかかわらず，出席率 がよく，会員非会員合わせて76人が参加した。 大会後約 70 人が生協に集まり, 盛大に㤅親会を 開催した。会場の使用を許可された大学当局を 始め, 第 2 解剖学教室全員, その他飞貴重な時 間をさいて惜しみなく手伝って下さった教官, 学生, 会員の御身内などの皆々様に梁く感謝の 意を表したい。

(R. ゴリス)

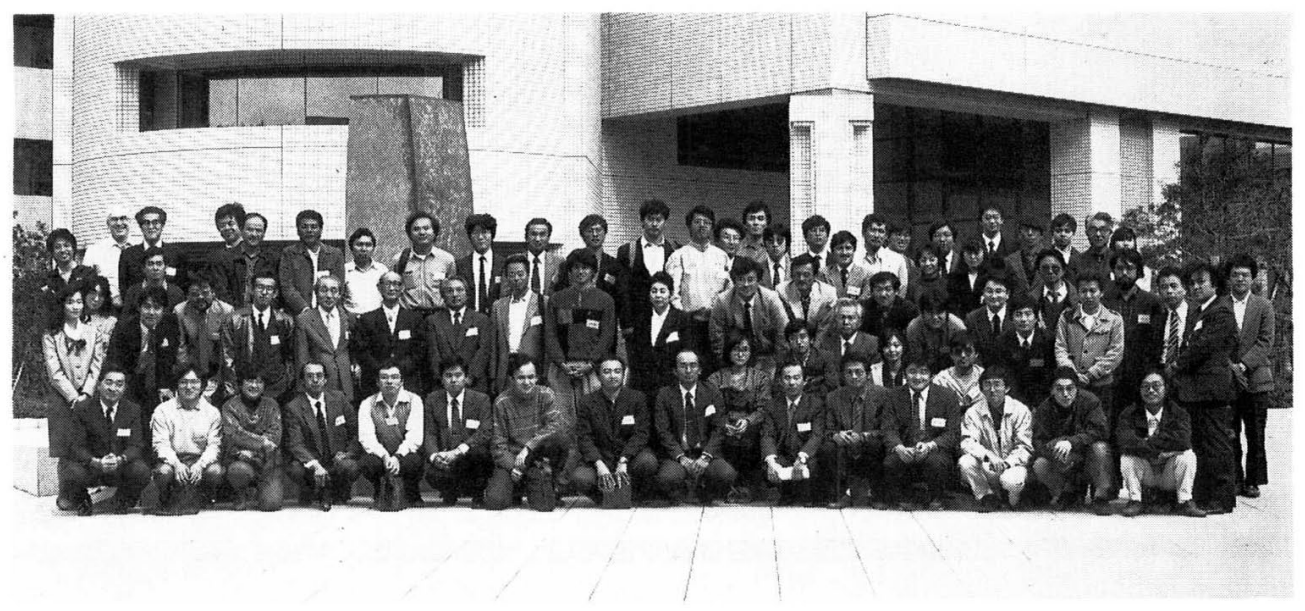

\section{講演要旨}

1. 沿海州のニホントカゲについて

$$
\text { 正田 努(宗大・理・動物) }
$$

Notes on Eumeces latiscutatus from Primor'e, USSR. Tsutomu Hikida

1888年にブルツェフが沿海州のソビエッッカヤ・ガ バニ, ウラジミール湾, オリガ湾から採集した 7 個体 のトカゲはエルパチェフスキイとサバネエフ(1906)に よって, 日本列島のトカゲと同種だとされ, Eumeces marginatus の学名で報告された。その後日本列島の トカゲは琉球列島のあのと别種の二ホントカゲ $E$. latiscutatus とされ, 以後, ソ連の研究者は沿海州の このトカゲはニホントカゲとして扱ってきたが，日本 列島から飛び離机て分布するこの集団が別種の可能性 も指摘されてきた。たとえば，ニコルスキイ (1915) は扔そらく二ホントカゲだろうとしながら, 別種や末 記載種の可能性も指摘し， スタイネガー (1925) やテ 